\title{
AN ANALYSIS OF NATIONAL-STATE-DISTRICT LEVEL ACREAGE AND PRODUCTION ESTIMATES OF RABI SORGHUM UNDER FASAL PROJECT
}

\author{
Dolly*, Shalini Saxena, S. K. Dubey, K. Choudhary, Seema Sehgal, Neetu and S. S. Ray \\ Mahalanobis National Crop Forecast Centre, DAC\&FW, Pusa, New Delhi-110012, India (dolly11fri, seemasehgal93)@gmail.com, \\ (shalini.85, sunil.dubey86,karan.c)@gov.in, (neetu.ncfc, shibendu.ncfc)@nic.in
}

Commission III, WG III/10

KEY WORDS: FASAL, Sorghum, Remote Sensing, Landsat 8 OLI, LISS III, Sentinel 2A, Ground Truth

\begin{abstract}
:
Sorghum (Sorghum vulgare Pers.) popularly known as jowar is the most important food and fodder crop of dry land agriculture. It is generally grown in both Kharif and Rabi season, with sown area of 25.3 and 38.3 lakh ha, respectively, at National level. The major states contributing to national sorghum acreage are Karnataka and Maharashtra. Crop acreage and yield estimation is of great significance to develop food policies and economic plans for a country. In this regard, under FASAL project, Sorghum production estimation is being carried out since 2013-14. Data from December to January is used for classification considering the peak season of crop. The satellite data used for classification has been gradually changed from Resourcesat 2 LISS III/ Landsat 8 OLI to Sentinel 2. Ground Truth has played major role to support the classification methodology. Total 1,409 GT points have been collected so far for both the states, with the help of state agriculture departments. NDVI based Crop Cutting Experiment (CCE) points are also generated and given to State for conducting the experiments at ground level. District level Sorghum crop yield is estimated using two procedures - i) Agro-meteorological regression models, ii) Remote sensing index based empirical models. The state and district level estimates were compared with government estimates. At state level the RMSE was found ranging from $6.5 \%$ to $34.7 \%$ and correlation (r) was found ranging from 071 to 0.87. At district level, the correlation between FASAL project estimates and government estimates ranged between 0.80 to 0.95 . Overall, the paper discusses, the experience gained from the Rabi sorghum production estimation, in last 5 years, under FASAL project and the scope of improvement.
\end{abstract}

\section{INTRODUCTION}

Sorghum, which is locally known as jowar, is the most important fodder crop of dryland agriculture, in India. Sorghum is generally grown both Kharif and Rabi season, with sown area of 25.3 and 38.3 lakh ha, respectively. Sorghum has originated in India and Africa. It is also said that its origin is Abyssinia and from there it was brought to USA and European countries (http://www.farmerfriend.info/Sorghum.html). Jowar is mainly concentrated in the peninsular and central India. The major states contributing to national Sorghum acreage, during Rabi (winter) season, are Karnataka and Maharashtra. In India, these two states aggregate to $90 \%$ of Rabi Sorghum acreage and $81.5 \%$ of Rabi Sorghum production (based on DES data of 2012-13 to 2016-17). Other states like Andhra Pradesh, Gujarat, Rajasthan, Uttar Pradesh \& Tamil Nadu grow sorghum in small areas primarily for fodder. In Southern India, sorghum crop is grown during Rabi \& summer seasons. Rabi Sorghum is sown in the month of October to November. Sorghum plants are very hardy and can withstand high temperature and drought. It may be successfully grown under atmospheric temperature ranging between $15^{\circ} \mathrm{C}$ to $40^{\circ} \mathrm{C}$ and annual rainfall ranging from 400 to $1000 \mathrm{~mm}$ (https://www.indiaagronet.com/indiaagronet/ crop\%20info/jower.htm). It is grown on a variety of soil types but the clayey loam soil rich in humus has been found to be the ideal soil. A good sorghum soil must have an efficient drainage facility though; it may withstand water logging more than maize.
Timely and reliable estimate of crop area and production is important to support food crop management and food security programmes (Ray et al., 2014). Satellite based remote sensing data analysis has been playing vital role in pre harvest crop acreage estimation. Crop acreage estimation presents several challenges and complexities, which may not be readily apparent (Craig and Atkinson, 2013). Small field sizes, diversified cropping pattern, different crop sowing time and availability of satellite data are some of the major challenges in estimation of crop area using remote sensing data (Ray and Neetu, 2017). These problems can be overcome by estimation at multiple stages: before sowing (specifically, the date of intended sowing, which depends upon the profits obtained in the previous year from the crop and weather forecasts); during early sowing; at mid-season and before harvest (Vogel and Bange 1999). Being a rabi crop, optical satellite data for sorghum can be easily obtained for analysis.

FASAL (Forecasting Agricultural output using Space, Agrometeorology and Land based observations) is a major operational programme of Ministry of Agriculture and Farmers Welfare, Govt of India under which MNCFC has been regularly generating multiple pre-harvest crop acreage and production forecasts at District/State/National level for 8 major crops of the country since 2012 (Ray and Neetu, 2017). Rabi Sorghum is one of those 8 major crops. Sorghum production forecasts have been generated since 2013-14. The purpose of this study is to analyse the forecasts generated under FASAL project for past 5 years' (2013-15 to 2017-18), vis-à-vis government estimates.

\footnotetext{
* Corresponding author
} 


\section{STUDY AREA}

The district level area and production estimates are carried out in 20 major districts in the state of Karnataka and Maharashtra (Figure 1) that accounts for $90 \%$ of Rabi sorghum acreage and $81.5 \%$ of Rabi sorghum production. In each state, the major districts growing Rabi Sorghum crop have been selected for the analysis.

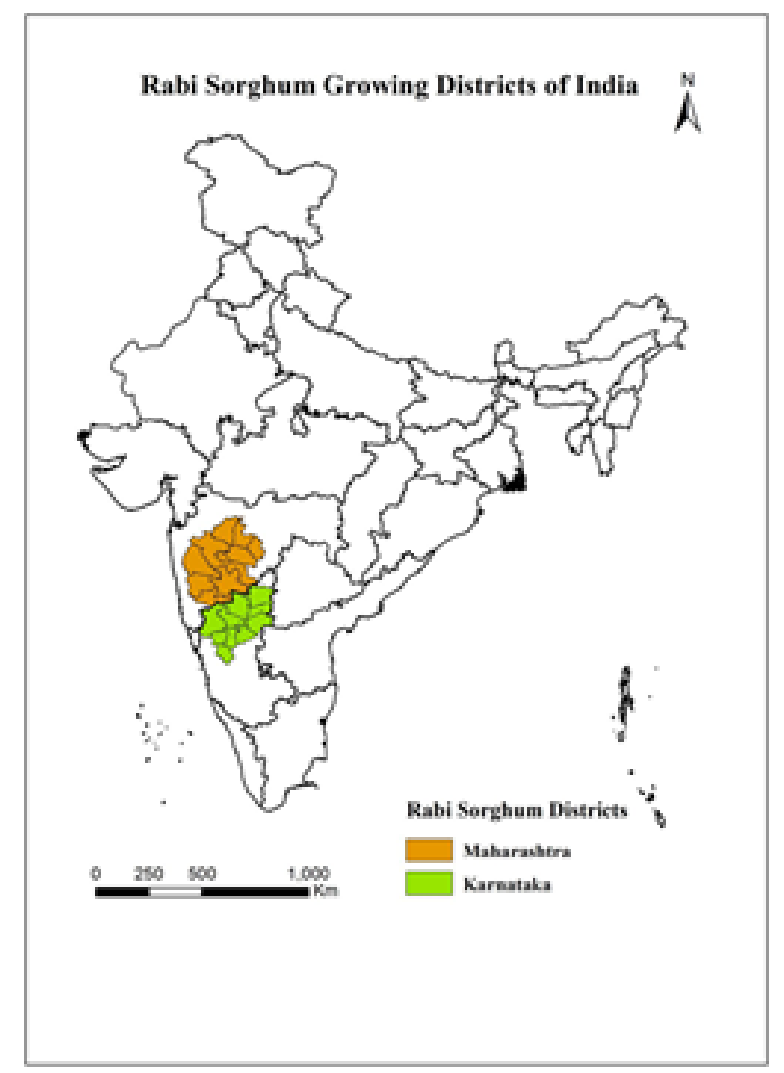

Figure 1. Rabi Sorghum growing districts of India, for which area and production estimates are carried out under FASAL project

The State-wise contribution of Rabi Sorghum area and production of the country is shown in Figure 2. Maharashtra state is covering total $64 \%$ of the Rabi Sorghum area and $45.2 \%$ of the production, while Karnataka covers $26 \%$ Rabi sorghum area and is contributing $36.3 \%$, in terms of production in the country.

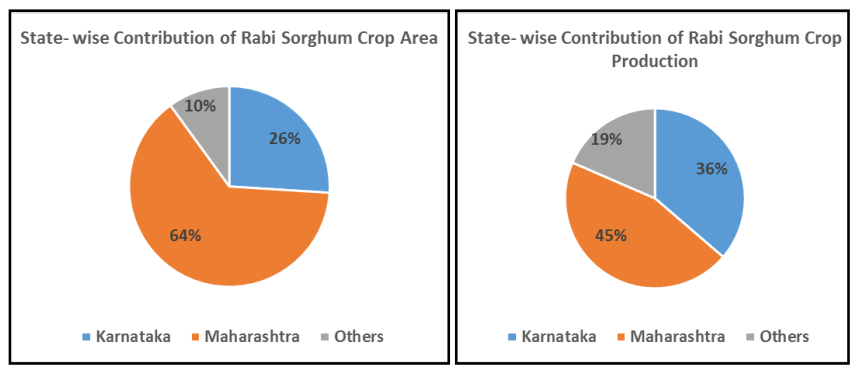

Figure 2. State-wise average (2012 to 2016) contribution to Rabi Sorghum area and production in the country (Source: DES, DAC\&FW)

Rabi Sorghum yield of Maharashtra is much lower than Karnataka, even though it has higher crop area. However,

because of higher area, the production of Rabi Sorghum is also higher in Maharashtra compared to Karnataka (Figure 3).

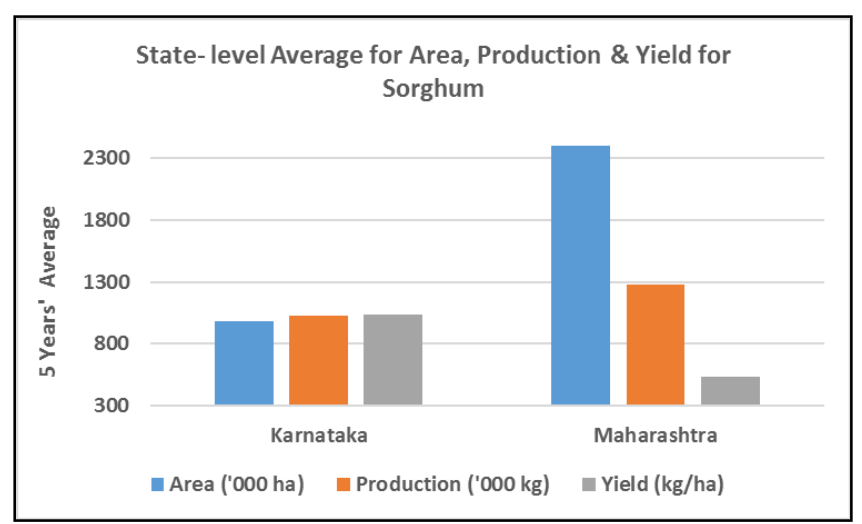

Figure 3. State-wise average (2012 to 2016) Rabi Sorghum Area, Production and Yield (Source: DES, DAC\&FW)

\section{MATERIALS AND METHODS}

\subsection{Satellite Data}

Single date Sentinel 2 MSI, Resourcesat 2 LISS III \& Landsat 8 OLI data have been used for sorghum analysis. The specifications of the satellite date are given in Table 1 .

\begin{tabular}{|l|l|r|r|r|r|}
\hline Satellite & Sensor & Bands & $\begin{array}{c}\text { Resolution } \\
(\mathrm{m})\end{array}$ & $\begin{array}{c}\text { Swath } \\
(\mathrm{km})\end{array}$ & $\begin{array}{c}\text { Repeatvity } \\
(\text { days })\end{array}$ \\
\hline Resoucesat-2 & $\begin{array}{l}\text { LISS } \\
\text { III }\end{array}$ & 4 & 23.5 & 141 & 24 \\
\hline Landsat-8 & OLI & 11 & 30 & 185 & 16 \\
\hline Sentinel-2 & MSI & 12 & 10 & 290 & 10 \\
\hline
\end{tabular}

Table 1. Specifications of the satellite data used in Rabi Sorghum Analysis

Moderate resolution remote sensing data of MODIS (Moderate Resolution Imaging Spectroradiometer) on-board Terra/Aqua Satellite was used for developing remote sensing-based index (Vegetation Condition Index).

For Karnataka \& Maharashtra, data from December to early January was used. Example of a multi-date LISS III data of, showing Rabi Sorghum crop is shown in figure 4.

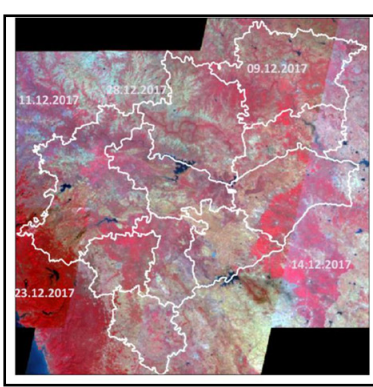

(a)

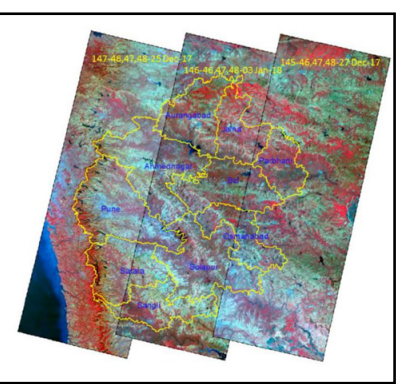

(b) 
Figure 4. Resourcesat 2 LISS III Satellite Images (False Colour Composite) of Rabi Sorghum districts, a) Karnataka b) Maharashtra

\subsection{Ground Truth Data}

Ground truth data is essential for the analysis of remote sensing data for differentiating various land uses and land covers. The ground truth data is collected by the state government officials using a smartphone-based Android application, called Bhuvan FASAL, developed by NRSC (ISRO) (Figure 5). The application is used to collect attribute information related to ground truth feature observed along with field photograph and sketch which can be directly uploaded to Bhuvan Geoportal server in real time manner. The ground truth data for sorghum crop was generally collected during November- December each year. Number of GT sites in different years are presented in Figure 6.

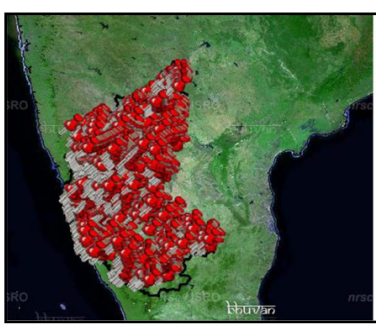

(a)

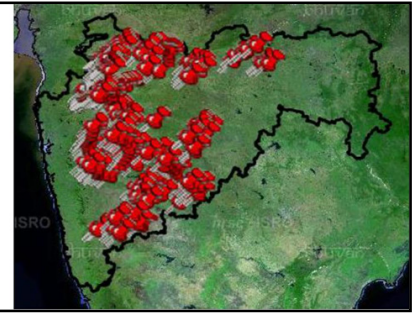

(b)
Figure 5. GT points on Bhuvan portal for a) Karnataka and b) Maharashtra, collected during Nov-Dec, 2017

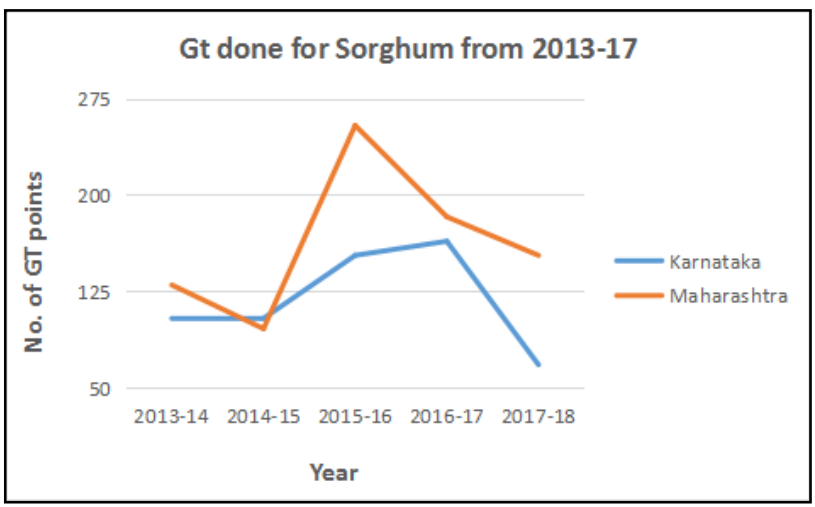

Figure 6. State-wise number of GT points collected for Rabi Sorghum from 2013-14 to 2017-18

\subsection{Crop Classification and Acreage Estimation}

During 2013-14, stratified sample segment method \& supervised classification approach was used. But, since 2014, crop classification is a two-step process comprising of optimum date selection and classification. Unsupervised classification was carried out on the multi-spectral (3-4 bands) dataset to identify the land use classes. Within crop classes, supervised/ unsupervised classification approach was followed using ground truth sites collected by state agricultural department officials. Signatures of Rabi Sorghum crop and other land cover features are identified using ground truth data. The maximum likelihood classifier is used which calculates the probability of a pixel belonging to a particular class (Lillesand and Kiefer, 2000). Mean DN (Digital number) values of different crops as observed in multispectral data are given in Figure 7. Rabi Sorghum generally has higher values in NIR band compared to the other competing crop. After the classification Rabi Sorghum crop mask is generated and accuracy of the classified results is verified using ground truth. Then the Rabi Sorghum classified image is used to generate the acreage estimates, by overlaying the district boundary. Additional data used for crop classification include agricultural crop mask, collected from LULC mapping programme of NRSC (NRSC, 2006).

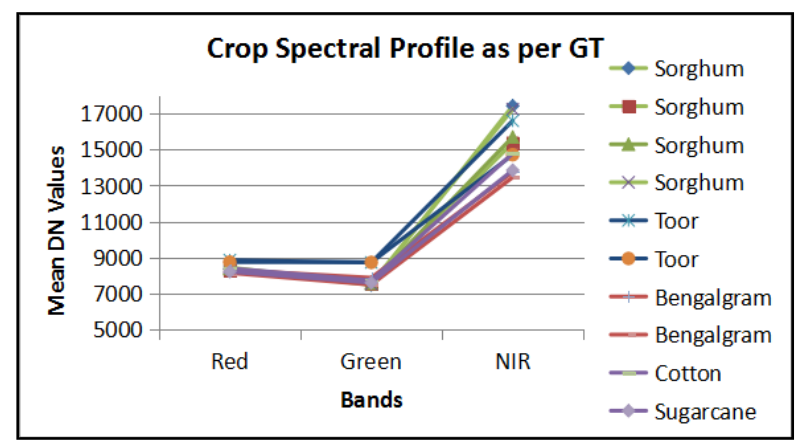

Figure 7. Mean Number values of different crops as seen in multi-spectral data (Green lines: Rabi Sorghum and Red \& Blue lines: Other Crop) for Karnataka in the year 2017

An example of classified Rabi Sorghum crop is given in Figure 8.
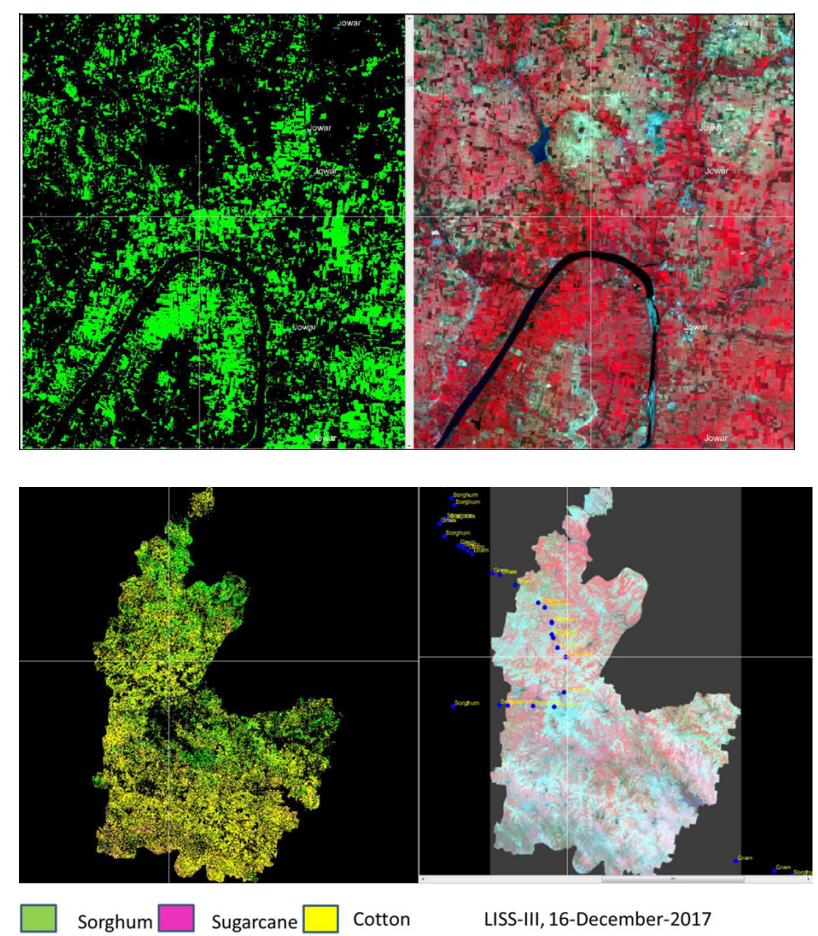

Figure 8. Classified image of Rabi Sorghum (green colour) and corresponding satellite image (FCC) for (above) Kalaburgi District, Karnataka (LISS III, Dec 2017) and (below) Jalna District, Maharashtra (LISS III, Dec 2017)

\subsection{Yield Estimation}

District level Rabi sorghum yield has been estimated using two procedures - i) Agro-meteorological regression models (Ghosh et al., 2014), ii) Remote sensing (NDVI, NDWI, VCI) based empirical models (Dubey et al., 2016).

Weather based yield estimation has been carried out using weekly weather (Rainfall, Maximum temperature, Minimum 
Temperature, Maximum and Minimum Relative Humidity) data of last 10-15 years, using data up to 2nd Fortnight of December every year.

Remote sensing-based Rabi sorghum yield was estimated using MODIS NDVI \& NDWI data as well as Vegetation Condition Index (VCI). For VCI computation, data from 2006 to 2017 during Rabi Sorghum growing period $\left(1^{\text {st }}\right.$ Fortnight of October to $2^{\text {nd }}$ Fortnight of December) were used. Step wise regression analysis was carried out between DES reported yield and fortnightly NDVI \& NDWI. Wherever the NDVI \& NDWI relations were not significant VCI was used to find out the best fit. This empirical model was used to compute the district level yield.

District level yield estimates, derived from the above two approaches, were combined statistically, giving weightage to respective models' $\mathrm{F}$ values, to get the final yield estimate.

Production estimates were generated by multiplying area and yield estimates. A summary of the Rabi Sorghum crop estimation process, during 4-year period, is given in Table 2.

\begin{tabular}{|c|c|c|c|c|c|}
\hline Year & $\begin{array}{c}\text { Satellite } \\
\text { Data }\end{array}$ & $\begin{array}{l}\text { Data } \\
\text { Period }\end{array}$ & $\begin{array}{c}\text { No. of GT } \\
\text { Points }\end{array}$ & $\begin{array}{c}\text { Image } \\
\text { Analysis } \\
\text { Approach }\end{array}$ & \begin{tabular}{|c|} 
Yield \\
Estimation \\
Approach
\end{tabular} \\
\hline $\begin{array}{c}2013 \\
14\end{array}$ & R2 LIII & $\begin{array}{c}11^{\text {th }}-30^{\text {th }} \\
\text { Dec }\end{array}$ & --- & \multirow{5}{*}{$\begin{array}{l}\text { Supervised } \\
\text { MXL } \\
\text { classification }\end{array}$} & \multirow{3}{*}{$\begin{array}{l}\text { Agromet } \\
\text { Model }\end{array}$} \\
\hline $\begin{array}{c}2014 \\
15\end{array}$ & $\begin{array}{l}\text { R2 LIII \& } \\
\text { L8 OLI }\end{array}$ & $\begin{array}{l}3^{\text {rd }} \text { Dec- } \\
11^{\text {th }} \text { Jan }\end{array}$ & 384 & & \\
\hline $\begin{array}{c}2015 \\
16\end{array}$ & S2 MSI & $\begin{array}{l}7^{\text {th }} \text { Dec- } \\
6^{\text {th }} \text { Jan }\end{array}$ & 407 & & \\
\hline $\begin{array}{c}2016 \\
17\end{array}$ & $\begin{array}{l}\text { R2 LIII, } \\
\text { L8 OLI \& } \\
\text { S2 MSI }\end{array}$ & $\begin{array}{c}8^{\text {th }} \text { Dec- } \\
7^{\text {th }} \text { Jan }\end{array}$ & 349 & & \multirow{2}{*}{$\begin{array}{l}\text { Agromet } \\
\text { Model, } \\
\text { Vegetation } \\
\text { Index } \\
\text { based } \\
\text { Model }\end{array}$} \\
\hline $\begin{array}{c}2017 \\
18\end{array}$ & $\begin{array}{l}\text { R2 LIII, } \\
\text { L8 OLI \& } \\
\text { S2 MSI }\end{array}$ & $\begin{array}{l}9^{\text {th }} \text { Dec- } \\
3^{\text {rd }} \text { Jan }\end{array}$ & 221 & & \\
\hline
\end{tabular}

R2 LIII - Resourcesat 2 LISS III, L8 OLI- Landsat 8 OLI, S2 MSI- Sentinel 2 MSI

Table 2. Summary of Rabi Sorghum Crop Estimation Process (2013-17)

\subsection{Accuracy Assessment}

The accuracy assessment was done at 2 level, i) Classification Accuracy Assessment through confusion matrix, ii) comparison of estimates with the governments' (Directorate of Economics $\&$ Statistics, DES) estimates.

\section{RESULTS AND DISCUSSION}

\subsection{Area, Yield and Production Assessment}

As mentioned earlier, the Rabi Sorghum Area, Production and Yield were estimated at district, state and national level. The Area (Million Ha) and Production (Million Tonnes), at national level is shown in Figure 9. There is a decreasing trend of both area and production.

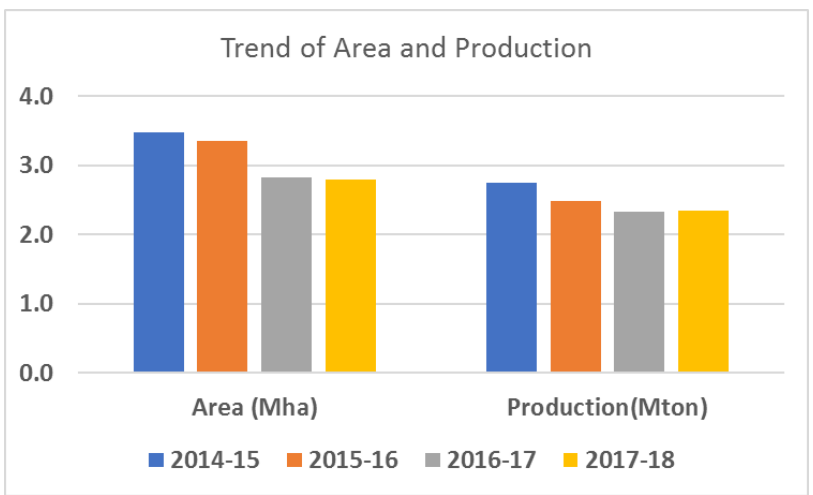

Figure 9. Trend of Rabi Sorghum Area (Million Ha) and Production (Million Tonnes), in the country, during four years

\subsection{Accuracy Assessment}

Accuracy assessment is an important step in the process of verifying and validating the analysed remote sensing data. The most common way to express classification accuracy is the preparation of error matrix also known as confusion matrix or contingency matrix. Such matrices show the cross tabulation of the classified land cover and the actual land cover reported by ground truth and calculation of overall accuracy of classification. Kappa $(\hat{\mathrm{H}})$ coefficient (Cohen, 1960) is another method of assessing accuracy which is a measure of overall agreement of a matrix. In contrast to the overall accuracy - the ratio of the sum of diagonal values to total number of cells counts in the matrix - the Kappa coefficient takes also nondiagonal elements into account. Table 3 shows confusion matrix and Kappa coefficient in the state of Karnataka. It shows an overall accuracy of $89.47 \%$ and Kappa Coefficient as 0.8291 . Out of 66 GT points, 55 were correctly identified as sorghum. Since there was clear distinction of sorghum and pulses at the time of classification due to different sowing dates (sorghum is early and pulses are late sown), therefore none of the sorghum classes were misclassified in pulses.

\begin{tabular}{|l|r|r|r|r|r|r|}
\hline \multirow{2}{*}{ Classified } & \multicolumn{4}{|c|}{ Ground Truth } & \multicolumn{2}{|c|}{ Accuracy (\%) } \\
\cline { 2 - 7 } & Sorghum & Pulses & Cotton & Others & Producer's & User's \\
\hline Sorghum & 55 & 0 & 0 & 1 & 98.21 & 83.33 \\
\hline Pulses & 0 & 32 & 3 & 1 & 88.89 & 94.12 \\
\hline Cotton & 0 & 1 & 0 & 1 & 0.00 & 0.00 \\
\hline Others & 11 & 1 & 3 & 100 & 86.96 & 97.09 \\
\hline Total & 66 & 34 & 6 & 103 & & \\
\hline Overall Accuracy: $89.47 \%$ \%appa Statistics: 0.8291 \\
\hline
\end{tabular}

Table 3. Confusion Matrix showing the Rabi Sorghum Classification Accuracy

\subsection{Comparison with Government Estimates}

\subsubsection{National- level Comparison}

Five years' (2013-14 to 2017-18) sorghum crop area and production estimates of Remote Sensing based (FASAL) \& Government (DES) were compared where it was observed that 
FASAL estimates are lower than DES estimates in most of the years, except for 2013-14. This may due to the fact that, while DES provides the sown area, remote sensing-based estimates provide estimates of standing crop. So, the crop which have been sown but failed to emerge or failed in early stages, will not be assessed by remote sensing.

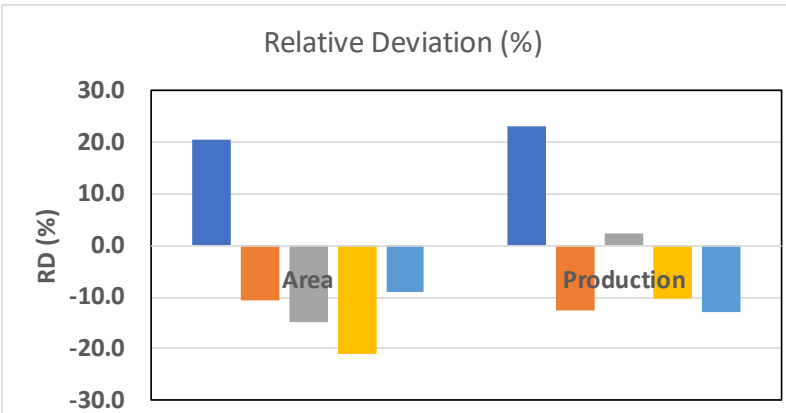

2013-14 2014-15 2015-16 2016-17 | 2017-18

Figure 10. Relative Deviation (\%) of Rabi Sorghum area and production estimates of FASAL and DES from 2013-14 to 2017-18

\subsubsection{State- level comparison}

The state level FASAL area and production estimates showed correlation of 0.87 and 0.71 , respectively, with DES estimates. The RMSE (Root Mean Square Error) values, when compared with DES estimates were low for Karnataka State, but higher for Maharashtra State (Table 4). RMSE values were lower for area estimates and higher for production estimates, because it included deviation of yield estimates.

\begin{tabular}{|l|r|r|}
\hline \multirow{2}{*}{ States } & \multicolumn{2}{|c|}{ RMSE (\%) } \\
\cline { 2 - 3 } Karnataka & Area & \multicolumn{2}{|c|}{ Production } \\
\hline Maharashtra & 6.5 & 10.9 \\
\hline
\end{tabular}

Table 4. Root Mean Square Error (\%) of Area and Production Estimates for different states for Rabi Sorghum

\subsubsection{District- level comparison}

District level Rabi Sorghum estimates, generated under FASAL project, were compared with government estimates 3 years from 2013 to 2015, depending upon availability of data. The correlation graphs for Area, Production and Yield are presented in Figure 11. The correlation was very high for area estimates, but low for yield and production estimates.
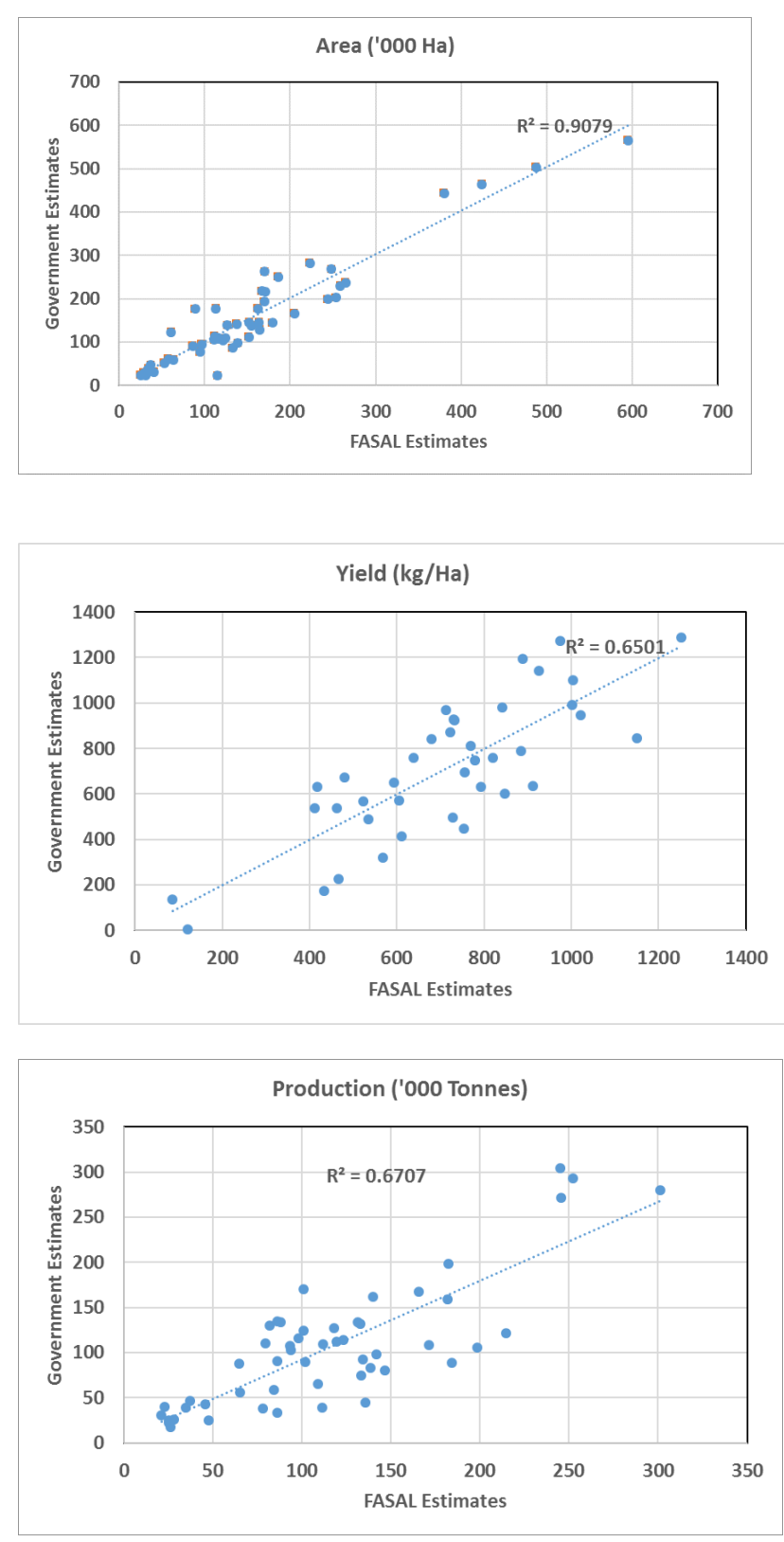

Figure 11. Comparison of District level Rabi Sorghum estimates of area, production and yield under FASAL project, with that of government estimates

\section{SUMMARY \& CONCLUSIONS}

Pre- harvest sorghum area assessment can help in decisions related to crop management, marketing, procurement, and to support food security programmes. The district level area and production estimates were carried out in 20 Rabi Sorghum growing districts of Karnataka \& Maharashtra. Sentinel 2, LISS III and Landsat 8 OLI data were analysed (as per availability) using hybrid classification technique to generate district level pre-harvest sorghum acreage estimation. Yield was estimated using agrometeorological and remote sensing-based models. The comparison of area and production estimates of FASAL project and the Government showed higher accuracies for area, compared to yield and production. However, in most cases correlations were high, showing the estimates were in the similar pattern, as per the actual data. The analysis also shows 
that, there is further need of improving the yield estimate models, for better accuracy.

\section{ACKNOWLEDGEMENTS}

The crop estimation work has been carried out under the FASAL (Forecasting Agricultural output using Space, Agrometeorology and Land based observations) of Department of Agriculture, Cooperation \& Farmers Welfare (DAC\&FW). The authors are thankful to the senior officials of DAC\&FW, for their strong support and keen interest in the work. The ground truth data collected and expert knowledge provided for remote sensing data analysis by the officials of the State Agriculture Departments and State Remote Sensing Centres, are gratefully acknowledged. The satellite data provided by ISRO (Resourcesat 2 \& 2A), ESA (Sentinel 2), NASA (MODIS \& Landsat-8) and the weather data provided by IMD are thankfully acknowledged. Thanks, are also due to the Analysts of FASAL team, who carried out the annual wheat crop analysis. Thanks are also due to scientists of SAC(ISRO), who developed the procedures for crop estimation under FASAL project.

\section{REFERENCES}

Cohen J. (1960). A coefficient of agreement for nominal scales. Educational and Psychological Epidemiology, 46 (5), 423-429

Craig M. and Atkinson D. (2013). A literature review of crop area estimation.

DES (2017) Agricultural Statistics at a Glance 2016. Directorate of Economics and Statistics, Department of Agriculture, Cooperation \& Farmers Welfare, Ministry of Agriculture \& Farmers Welfare, Government of India, 489p.

Dubey, S.K., Gavli, A.S., Yadav, S., Sehgal, S. and Ray, S.S. (2016). Index based approach of yield forecasting for Sugarcane
(Saccharum officinarum L.) crop in India. Fourth International Agronomy Congress, Nov 22-16, 2016, New Delhi.

Ghosh, K., Balasubramanian, R., Bandopadhyay, S. Chattopadhyay, N., Singh, K.K. and Rathore, L.S., (2014), "Development of crop yield forecast models under FASAL- a case study of kharif Rice in West Bengal". J. Agromet., 16 (1), $1-8$.

Lillesand, T.M. and Kiefer, R.W. (2000). Remote Sensing and Image Interpretation. John Wiley \& Sons, New York.

NRSC (2006) National Land use and Land cover mapping using multi-temporal AWiFS data. NRSA/LULC/1:250K/2006-2. National Remote Sensing Centre. 39p.

Pandey, Ashok (1992) Aspects of design of fermenter in solid state fermentation. Process Biochem

Ray, S. S. \& Neetu. 2017. Crop area estimation with Remote Sensing. In: J. Delincé (ed.), Handbook on Remote Sensing for Agricultural Statistics (Chapter 5). Handbook of the Global Strategy to improve Agricultural and Rural Statistics (GSARS): Rome. pp. 131-183.

Ray, S. S., Neetu, Mamatha, S. and Gupta, S. (2014) Use of Remote Sensing in Crop Forecasting and Assessment of Impact of Natural Disasters: Operational Approaches in India. Proceedings of the FAO Expert Meeting on Crop Monitoring for Improved Food Security, Vientiane, Lao PDR; 17 February 2014. (Ed.: M. K. Srivastava). RAP Publication 2014/28. FAO and ADB, 2015. pp. 111-121.

Vogel, F.A. and G.A. Bange. "Understanding USDA Crop Forecasts." 1999. Miscellaneous Publication No. 1554, U.S. Department of Agriculture, National Agricultural Statistics Service and Office of the Chief Economist, World Agricultural Outlook Board. 